\title{
Greenland Ice Sheet: Increased coastal thinning
}

\author{
W. Krabill, ${ }^{1}$ E. Hanna, ${ }^{2}$ P. Huybrechts, ${ }^{3,4}$ W. Abdalati, ${ }^{1}$ J. Cappelen, ${ }^{5}$ B. Csatho, ${ }^{6}$ \\ E. Frederick, ${ }^{7}$ S. Manizade, ${ }^{7}$ C. Martin, ${ }^{7}$ J. Sonntag, ${ }^{7}$ R. Swift, ${ }^{7}$ R. Thomas, ${ }^{7,8}$ \\ and J. Yungel ${ }^{7}$
}

Received 19 September 2004; revised 3 November 2004; accepted 19 November 2004; published 28 December 2004.

[1] Repeated laser-altimeter surveys and modelled snowfall/summer melt show average ice loss from Greenland between 1997 and 2003 was $80 \pm 12 \mathrm{~km}^{3} \mathrm{yr}^{-1}$, compared to about $60 \mathrm{~km}^{3} \mathrm{yr}^{-1}$ for 1993/4-1998/9. Half of the increase was from higher summer melting, with the rest caused by velocities of some glaciers exceeding those needed to balance upstream snow accumulation. Velocities of one large glacier almost doubled between 1997 and 2003, resulting in net loss from its drainage basin by about $20 \mathrm{~km}^{3}$ of ice between 2002 and 2003. INDEX TERMS: 1640 Global Change: Remote sensing; 1863 Hydrology: Snow and ice (1827); 4556 Oceanography: Physical: Sea level variations. Citation: Krabill, W., et al. (2004), Greenland Ice Sheet: Increased coastal thinning, Geophys. Res. Lett., 31, L24402, doi:10.1029/2004GL021533.

\section{Introduction}

[2] Recent observations show central parts of the Greenland Ice Sheet (GrIS) to be in balance, but with enough thinning at lower elevations to raise sea level by about

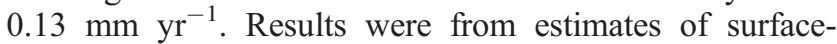
elevation change inferred from laser-altimeter surveys with NASA's Airborne Topographic Mapper (ATM) in 1993/94 repeated in 1998/99 [Krabill et al., 2000], and volume-budget comparison of snow accumulation with ice discharge [Thomas et al., 2001]. Although the aircraft measurements refer only to conditions during the interim between surveys, they agree closely with the volume-budget estimate indicating that the ice sheet above 2000-m elevation, taken as a whole, has been almost exactly in balance for the past few decades [Thomas et al., 2001].

[3] Low-elevation results were based only on aircraft measurements, primarily along outlet glaciers. These show widespread thinning at rates generally exceeding those expected from increased melting during recent warmer summers [Abdalati et al., 2001]. Consequently, part of the thinning was dynamic, possibly initiated by changes associated with the warming. If so, this calls into question

\footnotetext{
${ }^{1}$ NASA Goddard Space Flight Center, Greenbelt, Maryland, USA.

${ }^{2}$ Department of Geography, University of Sheffield, Sheffield, UK.

${ }^{3}$ Alfred-Wegener Institut für Polar-und Meersforschung, Bremerhaven, Germany.

${ }^{4}$ Also at Departement Geografie, Vrije Universiteit Brussel, Brussel, Belgium.

${ }^{5}$ Danish Meteorological Institute, Copenhagen, Denmark.

${ }^{6}$ Byrd Polar Research Center (BPRC), Ohio State University, Columbus, Ohio, USA.

${ }^{7}$ EG\&G, Inc., Wallops Flight Facility, Wallops Island, Virginia, USA.

${ }^{8}$ Also at Centro de Estudios Cientificos, Valdivia, Chile.
}

current prediction of sea-level rise in a warmer climate [Church et al., 2001] that includes only a very small dynamic glacier response. Here, we report results from aircraft surveys made since 1999 over many of the coastal regions surveyed earlier, showing overall increase in thinning rates consistent with more surface melting during warmer summers plus a substantial increase in dynamic thinning.

\section{Methods}

[4] Our estimates of surface-elevation change rates $(\mathrm{dh} / \mathrm{dt})$ are from comparison of ATM measurements, with elevation accuracy of $\sim 10 \mathrm{~cm}$ for flight lines of several hundred $\mathrm{km}$ [Krabill et al., 2002]. Recent surveys focussed on coastal regions in order to investigate areas undergoing most rapid changes so overall coverage is sparser than for 1993/4 and 1998/9 surveys, with higher-elevation coverage confined to the northern half of the ice sheet. At lower elevations, a strong seasonal elevation change is associated with brief periods of intense summer melting followed by slow thickening from snow accumulation and seaward ice motion. Consequently, comparison is best between surveys made during the same season. Most surveys were in May (exceptions were June/July 1993 and 1998), so we show results obtained by comparing recent data with surveys from 1997 and later, but not 1998. Results (Figure 1) show small changes in $\mathrm{dh} / \mathrm{dt}$ for high-elevation regions compared to earlier surveys, but a general trend towards thinning, possibly resulting from interannual variability in snowaccumulation rates [Davis et al., 2001].

[5] At lower elevations, thinning rates increased in most coastal regions, except in the SE. Here, the ice thickened by more than $1 \mathrm{~m}$ between May 2002 and May 2003, compared to thinning averaging $10-40 \mathrm{~cm} \mathrm{yr}^{-1}$ between 1993 and 1998 (Figure 2). This can be explained only by an approximate doubling in local precipitation in an area where accumulation rates are the highest in Greenland due to prevailing easterly winds, frequent cyclogenesis in and near Fram Strait, relatively low latitude, high moisture availability from an often warm ocean, and most importantly, orographic enhancement against steep coastal slopes. Precipitation commonly exceeds $1-2 \mathrm{~m}$ of water $\mathrm{yr}^{-1}$ in the SE, mostly in winter [Cappelen et al., 2001]. Unusually high accumulation in SE Greenland in 2002-3 is supported by an accumulation model driven by ECMWF (mainly ERA-40) analyses [Hanna et al., 2001, 2002; also Observed and modeled Greenland Ice Sheet snow accumulation, 1958-2003, and links with regional climate forcing, submitted to Journal of Climate, 2004, hereinafter referred to as Hanna et al., submitted manuscript, 2004]. Modelled snowfall, corrected for evaporation/sublimation, for the area 


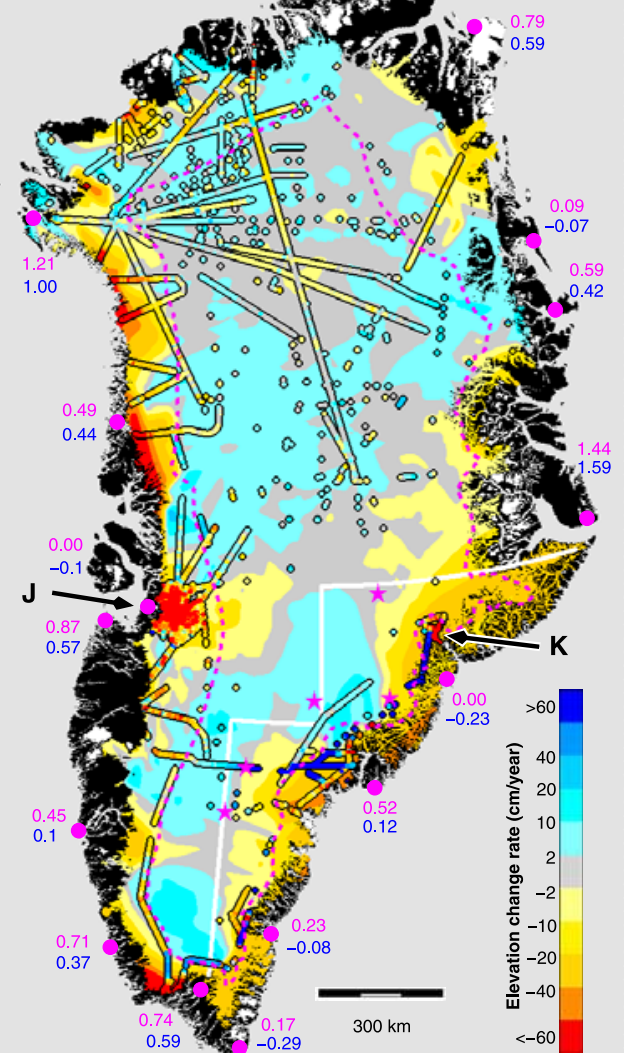

Figure 1. Rates of elevation change along ATM flight lines during 1997-2003, superimposed on a map of elevation-change rates resulting from the 1993/94 and 1998/99 surveys [Krabill et al., 2000]. Differences between average summer temperatures (June/July/August), and those for 1961-90, are listed at coastal weather stations, for 1997-2002 (upper) and 1993-99 (lower). The region outlined in the southeast consistently thinned until 2001, and then thickened substantially between May 2001 and May 2003. "J" and " $\mathrm{K}$ " show Jakobshavn Isbrae and Kangerdlugssuaq Gletscher. The broken line indicates the 2000 meter contour. Ice cores discussed in the text are marked by stars.

shown in Figure 1 was $1.21 \mathrm{~m}$ of water for June 2002-May 2003 , or $75 \%$ (3.5 standard deviations) above mean annual June-May (1958/9-2002/3) accumulation of $0.69 \mathrm{~m}$. This is unprecedented in at least the last 46 years of available analysis/model data, and in more than 100 years, based on data from nearby ice cores shown in Figure 1 (J. R. McConnell, personal communication, April 2004). The $0.5 \mathrm{~m}$ water equivalent of additional accumulation represents about $1.5 \mathrm{~m}$ depth of snow with density $\sim 330 \mathrm{~kg} \mathrm{~m}^{-3}$, in good agreement with observed thickening during the same period.

[6] Unusually high 2002/03 accumulation was almost certainly due to exceptionally high winter cyclonic activity over SE Greenland; mean sea level pressure charts (NCEP Operational dataset) show -5 to $-10 \mathrm{mb}$ anomalies over $\mathrm{S}$ Greenland from November 2002 to March 2003. The synoptic pattern over the northern North Atlantic was also exceptional based on records since at least 1990, and local snowfall should return to lower, near-'normal' values
(Hanna et al., submitted manuscript, 2004). However, enhancement of SE Greenland precipitation and more inter-annual variability with greater frequency of highly anomalous snowfall, may be hallmarks of ongoing climatic change [Church et al., 2001; Huybrechts et al., 2004].

[7] Despite extremely high 2002-03 snowfall in the SE, Figure 1 shows enhanced thinning of most coastal regions, consistent with recent summer temperatures considerably higher than for 1993-98, which were already warmer than the longer-term 1961-90 averages (Figure 1). We estimated total ice-sheet melt losses (runoff) during 1993-98 and 1997-2003, by comparing ECMWF-based estimates of runoff, corrected for variable snowfall and for water retained after percolation into surface snow [Huybrechts et al., 2004; Janssens and Huybrechts, 2000], with equivalent values for 1961-90. A monthly version of a degree-day runoff/retention model [Huybrechts et al., 2004] was used, with surface air temperature and precipitation/evaporation from ECMWF analyses, to calculate monthly runoff on a $5 \times 5 \mathrm{~km}$ grid. Surface air temperatures, corrected for orography errors in the ECMWF model, agree within $<1^{\circ} \mathrm{C}$ with weather station data. For 1961-90, runoff resulting from this approach was equivalent to $\sim 305 \pm$ $33 \mathrm{~km}^{3} \mathrm{yr}^{-1}$ of ice, very close to the average $\left(315 \mathrm{~km}^{3} \mathrm{yr}^{-1}\right)$ of several other model results [Church et al., 2001; Huybrechts et al., 2004]. Resulting estimates of net ice loss associated with melting/snowfall anomalies were $35 \pm$ $5 \mathrm{~km}^{3} \mathrm{yr}^{-1}$ for $1993-98$, and $46 \pm 7 \mathrm{~km}^{3} \mathrm{yr}^{-1}$ for $1997-$ 2003. Although these estimates are approximate, they indicate that melt losses increased over recent years.

[8] The 1993-98 excess runoff is about two thirds of the $51 \mathrm{~km}^{3} \mathrm{yr}^{-1}$ ice loss estimated by interpolation between measurements of elevation changes from repeat laseraltimeter surveys during this period [Krabill et al., 2000], but not including thinning rates $>1 \mathrm{~m} \mathrm{yr}^{-1}$ that were unlikely to be representative of less active surrounding ice. Instead, values were interpolated between measured thinning $<1 \mathrm{~m} \mathrm{yr}^{-1}$ and near-coastal thinning calculated as that caused only by anomalous melting consistent with warmer summers [Krabill et al., 2000; Abdalati et al.,

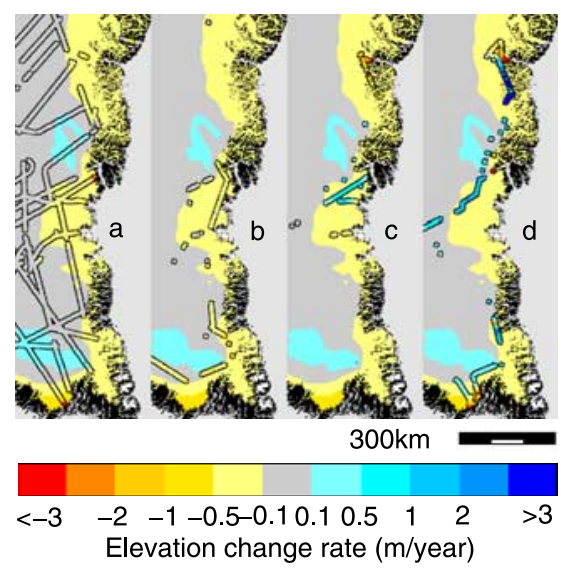

Figure 2. Rates of surface-elevation change $\left(\mathrm{m} \mathrm{yr}^{-1}\right)$ along the SE side of the ice sheet: (a) 1993-98; (b) 19972001; (c) 2001-02; (d) 2002-03. Background colors refer to 1993-98, and those along flight lines refer to the relevant time interval. Note change in color scale from Figure 1. 
2001]. The difference $\left(16 \mathrm{~km}^{3} \mathrm{yr}^{-1}\right)$ between total loss and excess runoff was probably caused by dynamic thinning [Abdalati et al., 2001], as glacier velocities exceeded "balance" values equivalent to total net accumulation within catchment basins. Although regions with thinning $>1 \mathrm{~m} \mathrm{yr}^{-1}$ were confined to faster parts of surveyed glaciers, the average volume loss of $51 \mathrm{~km}^{3} \mathrm{yr}^{-1}$ did not include net loss averaging $3 \mathrm{~km}^{3} \mathrm{yr}^{-1}$ from Kangerdlugssuaq Isbrae [Thomas et al., 2000] nor losses in the lower reaches of glaciers in the southeast. Here, volume budget calculations by Rignot et al. [2004] show losses of $17 \pm 4 \mathrm{~km}^{3} \mathrm{yr}^{-1}$ compared to our 1993-98 estimate for the same region [Krabill et al., 2000] of $12 \mathrm{~km}^{3} \mathrm{yr}^{-1}$. Other glaciers, particularly in the northwest, may also have lost additional ice by dynamic thinning, but probably less than those in the southeast. Consequently total losses from the ice sheet during 1993/4-98/9 were probably at least $59 \pm$ $15 \mathrm{~km}^{3} \mathrm{yr}^{-1}$ of ice, with about $24 \mathrm{~km}^{3} \mathrm{yr}^{-1}$ caused by dynamic thinning. Estimated errors include an arbitrary attempt to take account of the extensive interpolation between aircraft flight lines involved in estimating nearcoastal thinning rates. Between 1997 and 2003, thinning rates inferred from ATM surveys of several glaciers increased considerably, with enhanced thinning in the north and along the west coast, reaching elevations close to 2000-m. For example, many flights near the west coast and close to the $2000-\mathrm{m}$ contour show that thinning rates after 1997 were $10-40 \mathrm{~cm} \mathrm{yr}^{-1}$ higher than for 1993/4-98/9. At such high elevations increased summer melting is unlikely to have been enough to explain all of the enhanced thinning, and a change in regional ice dynamics appears to be occurring along much of the west and parts of the northern ice sheet. This is certainly the case for Greenland's fastest glacier - Jakobshavn Isbrae. Between 1991 and 1997, this glacier slowly thickened [Thomas et al., 2003], consistent with earlier balance calculations [Echelmeyer et al., 1992]. After 1997, the glacier began to thin at low elevations, with thinning rates progressively increasing and the thinning zone migrating inland (Figure 3). Between 1997 and 2003 , thinning rates averaged $>10 \mathrm{~m} \mathrm{yr}^{-1}$ within $20 \mathrm{~km}$ of the grounding line, with lower rates further inland, indicating an increase in longitudinal creep rates, ice velocity, and total ice discharge [Thomas et al., 2003]. Thinning rates now exceed $15 \mathrm{~m} \mathrm{yr}^{-1}$ along the main trunk of the glacier, and velocities near the seaward end rose from $7 \mathrm{~km}$ $\mathrm{yr}^{-1}$ in 1997 [Abdalati and Krabill, 1999] to $12 \mathrm{~km} \mathrm{yr}^{-1}$ in 2002 [Joughin et al., 2004]. The observed thinning and velocity increase represent a progressive increase in net ice loss from this one glacier to about $20 \mathrm{~km}^{3} \mathrm{yr}^{-1}$ in 2002-03, and averaging $10 \pm 2 \mathrm{~km}^{3} \mathrm{yr}^{-1}$ between 1997 and 2002.

[9] Until recently, the glacier terminated in a floating ice tongue, about $15 \mathrm{~km}$ long, between fjord walls $6-7 \mathrm{~km}$ apart. Surveys between 1997 and 2001 showed substantial retreat of the calving ice front, and thinning of the floating tongue by more than $300 \mathrm{~m}$ [Thomas et al., 2003]. Consequently, transition from slow thickening to rapid thinning was probably initiated by weakening of the floating ice tongue which, by May 2003, had almost totally broken away from the glacier. If so, discharge velocities should begin to decrease as the glacier thins and gravitational driving forces decrease, unless glacier sliding is also lubricated by the effects of increased surface meltwater

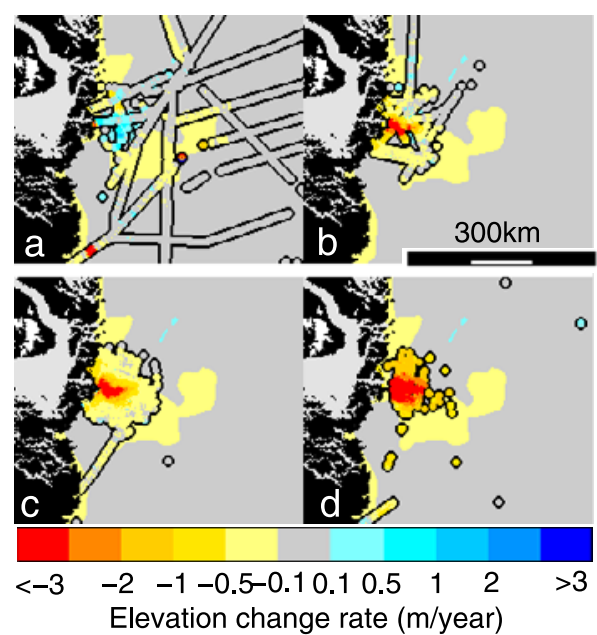

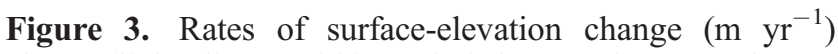
along flight lines within Jakobshavn Isbrae catchment basin: (a) 1993-98; (b) 1997-2001; (c) 1997-2002; (d) 2002-03.

draining to the bed [Zwally et al., 2002]. Such lubrication may be occurring on Kangerdlugssuaq Gletscher on the eastern side of the ice sheet (Figure 1) with no floating tongue [Thomas et al., 2000], where 1993-98 thinning rates (up to $10 \mathrm{~m} \mathrm{yr}^{-1}$ ) decreased between 1998 and 2001, and then increased to their former values. However, observed thinning rates here do not show any simple correlation with summer temperatures (and therefore melt-water abundance) at a nearby coastal weather station. They are more suggestive of sporadic, brief periods of glacier acceleration and very rapid thinning. This may imply ponding of water beneath the glacier until some threshold is reached, when velocities increase very rapidly and alter the glacier "plumbing" sufficiently to allow seaward drainage of the meltwater. Warming summers are likely to increase the frequency of such events.

[10] In order to estimate total losses from the ice sheet between 1997 and 2003, we assume that those resulting from dynamic changes were similar to those during 1993-98 $\left(24 \pm 10 \mathrm{~km}^{3} \mathrm{yr}^{-1}\right)$ plus the ice lost from Jakobshavn Isbrae $\left(10 \pm 2 \mathrm{~km}^{3} \mathrm{yr}^{-1}\right)$. Together with runoff losses for the same period of $46 \pm 7 \mathrm{~km}^{3} \mathrm{yr}^{-1}$ of ice, this implies a net loss of $80 \pm$ $12 \mathrm{~km}^{3} \mathrm{yr}^{-1}$ averaged over 1997-2003. By 2002-03, Jakobshavn losses had risen to $\sim 20 \mathrm{~km}^{3} \mathrm{yr}^{-1}$, approximately balancing the positive effects of anomalously high accumulation in the southeast that year. Moreover, we assumed that recently-increased thinning rates were solely caused by increased melting, apart from Jakobshavn Isbrae. Consequently, our estimated total loss may be conservative, during a period when losses progressively increased. Thus, rates of ice loss from Greenland since 1997 were 35\% higher than for 1993/4-98/9, with more than half from increased runoff and the remainder from progressively increased losses by dynamic thinning. Associated sea-level increase rose from about 0.15 to $0.2 \mathrm{~mm} \mathrm{yr}^{-1}$.

[11] Periodic, rapid thinning is not uncommon on individual glaciers, with timing determined by glacier characteristics [van der Veen, 1999], but for widespread glaciers to change in unison requires external forcing. Massive losses 
from Jakobshavn Isbrae were probably initiated by weakening and break-up of its floating ice tongue. But for other thinning glaciers without floating extensions, increased velocities may result from enhanced basal lubrication as more surface melt water drained to the bed during recent warmer summers. Detailed observations of fast glaciers have shown velocity to increase soon after intense melt events [O'Neel et al., 2001]. Similar behaviour has been confirmed for slower-moving parts of GrIS [Zwally et al., 2002], and we can expect this process to continue in a warming climate. Moreover, the rapid response of Jakobshavn Isbrae to changes in its floating extension is indicative of what we might expect as Antarctic ice shelves start to break up [De Angelis and Skvarca, 2003].

[12] Acknowledgments. We thank pilots, crew, and technicians who helped to make the airborne surveys, A. Stephens and the British Atmospheric Data Centre at Rutherford Appleton Laboratory, UK, for providing ERA-40 data, and J. McConnell (Desert Research Institute, Reno, Nevada) for providing information from shallow ice cores. The work was supported by NASA's Cryospheric Processes Program and ICESat Project, with support for P. Huybrechts from German HGFStategiefonds Projekt 2000/13 SEAL (Sea Level Change) and the Belgian Science Policy Office Second Programme on Global Change and Sustainable Development project MILMO (contract EV/10/9B).

\section{References}

Abdalati, W., and W. Krabill (1999), Calculation of ice velocities in the Jakobshavn Isbrae area using airborne laser altimetry, Remote Sens. Environ., 67, 194-204.

Abdalati, W., W. Krabill, E. Frederick, S. Manizade, C. Martin, J. Sonntag, R. Swift, R. Thomas, C. Wright, and J. Yungel (2001), Outlet glacier and margin elevation changes: Near coastal thinning of the Greenland Ice Sheet, J. Geophys. Res., 106, 33,729-33,741.

Cappelen, J., B. Jørgensen, E. Laursen, L. Stannius, and R. Thomsen (2001), The observed climate of Greenland, 1958-99-With climatological standard normals, 1961-90, Minist. of Transp. Tech. Rep. 00-18, Dan. Meteorol. Inst., Copenhagen.

Church, J., et al. (2001), Changes in sea level, in Climate Change 2001: The Scientific Basis: Contribution of Working Group I to the Third Assessment Report of the Intergovernmental Panel on Climate Change, edited by J. Houghton et al., pp. 639-694, Cambridge Univ. Press, New York.

Davis, C., J. McConnell, J. Bolzan, J. Bamber, R. Thomas, and E. MosleyThompson (2001), Elevation change of the southern Greenland Ice Sheet from 1978 to 1988: Interpretation, J. Geophys. Res., 106, 33,74333,754 .

De Angelis, H., and P. Skvarca (2003), Glacier surge after ice shelf collapse, Science, 299, 1560-1562.

Echelmeyer, K., W. Harrison, T. Clarke, and C. Benson (1992), Surficial glaciology of Jakobshavn Isbræ, West Greenland; Part II. Ablation, accumulation and temperature, J. Glaciol., 38, 169-181.

Hanna, E., P. Valdes, and J. McConnell (2001), Patterns and variations of snow accumulation over Greenland, 1979-98, from ECMWF analyses, and their verification, J. Clim., 14, 3521-3535.
Hanna, E., P. Huybrechts, and T. Mote (2002), Surface mass balance of the Greenland Ice Sheet from climate analysis data and accumulation/runoff models, Ann. Glaciol., 35, 67-72.

Huybrechts, P., J. Gregory, I. Janssens, and M. Wild (2004), Modelling Antarctic and Greenland volume changes during the 20th and 21st centuries forced by GCM time slice integrations, Global Planet. Change, 42, 83-105, doi:10.1016/j.gloplacha.2003.11.011.

Janssens, I., and P. Huybrechts (2000), The treatment of meltwater retention in mass-balance parameterisations of the Greenland ice sheet, Ann. Glaciol., 31, 133-140.

Joughin, I., W. Abdalati, and M. Fahnestock (2004), Large fluctuations in speed on Greenland's Jakobshavn Isbræ glacier, Nature, 432, 608610 .

Krabill, W., W. Abdalati, E. Frederick, S. Manizade, C. Martin, J. Sonntag, R. Swift, R. Thomas, C. Wright, and J. Yungel (2000), Greenland ice sheet: High-elevation balance and peripheral thinning, Science, 289, $428-430$

Krabill, W., W. Abdalati, E. Frederick, S. Manizade, C. Martin, J. Sonntag, R. Swift, R. Thomas, and J. Yungel (2002), Aircraft laser altimetry measurement of elevation changes of the Greenland ice sheet: Technique and accuracy assessment, J. Geodyn., 34, 357-376.

O'Neel, S., K. Echelmeyer, and R. Motyka (2001), Short-term flow dynamics of a retreating tidewater glacier: LeConte Glacier, Alaska, USA, J. Glaciol., 47, 567-578.

Rignot, E., D. Braaten, P. Gogineni, W. Krabill, and J. McConnell (2004), Rapid ice discharge from southeast Greenland glaciers, Geophys. Res. Lett., 31, L10401, doi:10.1029/2004GL019474

Thomas, R., W. Abdalati, T. Akins, B. Csatho, E. Frederick, S. Gogineni, W. Krabill, S. Manizade, and E. Rignot (2000), Substantial thinning of a major east Greenland outlet glacier, Geophys. Res. Lett., 27, 12911294.

Thomas, R., B. Csatho, C. Davis, C. Kim, W. Krabill, S. Manizade, J. McConnell, and J. Sonntag (2001), Mass balance of higher-elevation parts of the Greenland ice sheet, J. Geophys. Res., 106, 33,707-33,716.

Thomas, R., W. Abdalati, E. Frederick, W. Krabill, S. Manizade, and K. Steffen (2003), Investigation of surface melting and dynamic thinning on Jakobshavn Isbrae, Greenland, J. Glaciol., 49, 231-239.

van der Veen, C. (1999), Mountain glaciers, in Fundamentals of Glacier Dynamics, chap. 10,309-346, A. A. Balkema, Brookfield, Vt.

Zwally, H., W. Abdalati, T. Herring, K. Larson, J. Saba, and K. Steffen (2002), Surface melt-induced acceleration of Greenland Ice-Sheet flow, Science, 297, 218-222.

W. Abdalati and W. Krabill, NASA/GSFC, Greenbelt, MD, USA. (waleed.abdalati@nasa.gov; william.b.krabill@nasa.gov)

J. Cappelen, Danish Meteorological Institute, Lyngbyvej 100, DK-2100 Copenhagen, Denmark. (jc@dmi.dk)

B. Csatho, BPRC, 1090 Carmack Road, Ohio State University, Columbus, OH 43210-1002, USA. (csatho.1@osu.edu)

E. Frederick, S. Manizade, C. Martin, J. Sonntag, R. Swift, R. Thomas, and J. Yungel, EG\&G, Inc., NASA Wallops Flight Facility, Wallops Island, VA 23337, USA. (earlb@osb.wff.nasa.gov; manizade@osb.wff.nasa.gov; martin@osb.wff.nasa.gov; sonntag@osb.wff.nasa.gov; swift@osb.wff.nasa. gov; thomas@osb.wff.nasa.gov; yungel@osb.wff.nasa.gov)

E. Hanna, Department of Geography, University of Sheffield, Sheffield S10 2TN, UK. (ehanna@sheffield.ac.uk)

P. Huybrechts, Departement Geografie, Vrije Universiteit Brussel, Pleinlaan 2, B-1050 Brussel, Belgium.(phuybrec@vub.ac.be) 